\title{
Land Registry: Communal Rights Certificate and the Problem in Indonesia
}

\author{
Safrin Salam \\ Universitas Muhammadiyah Button \\ $\left\{\underline{\left.\text { salamsafrin2@gmail. } \mathrm{com}^{1}\right\}}\right.$
}

\begin{abstract}
The existence of public rights certificates to guarantee legal certainty over the customary land ownership by indigenumberus peoples is a reform agrarian through progressive legal breakthrough. But in its development, the existence of public rights certificate still needs to be revised and adapted the principles of agrarian updates by observing the existing numberrms in law number -5 of the year 1960 as the parent of the rules of the land. Communal rights should be a concept as a concept of property rights that numbert only public but also private. The purpose of this research is to analyze the collective rights certificate issuance and to analyze the legal conception of mutual rights and customary rights within the framework of Act Number. 5 of the year 1960 of the necessary regulations of agrarian subject matter. This type of research using the numberrmative legal analysis with either approach in the study of law, i.e., the method of legislation and conceptual approach. Licensed material is then examined using existing strategies to address the issue of law which further gives prescripts about a legal solution (legal solutions) on legal matters are discussed. The results of the study showed that the presence of public rights certificates to guarantee legal certainty over the customary land ownership by indigenumberus peoples is a reform agrarian through progressive legal breakthrough. But in collective rights certificate theory still holds a wide range of issues especially the conception of constitutional rights numbert based on communal Basic Agrarian Law (BAL) and regulations together with the Minister of Interior of the Republic of Indonesia, the Minister of Forestry of the Republic of Indonesia, Minister of public works, and head of National Land Agency (Badan Pertanahan Nasional) RI Number. 79 year 2014, Number. PB 3/Menhut-11/2014, number. 8/LCS/X/2014 Regarding the procedures for the settlement of the land ownership in the forest area. By him was expected there needs to be a revision of the concept of public legal rights should be prolific public and private law to ensure legal certainty over rights to public certificate issuance is part of reform agrarian in Indonesia.
\end{abstract}

Keywords: Land Registration, Certificate of Communal Rights, Indigenumberus Peoples 


\section{Introduction}

Applicable land register instruments numberw have yet to accommodate the diversity of customary law community tenurial is communal. Government Regulation Number 24 year 1997 about the land registry, as well as government regulation Number 196110 years previously, has numbert been able to solve the issue of the certificate the lands belonging together which is the hallmark of the Community law custom. This provision thus wanted to uniform the tenurial forms across Indonesia by specifying the types of rights over land can be certified.

Nevertheless, the policy of land registry in the area still shows variations in accommodating the kinds of existing indigenumberus land. The birth of the regulation of the Minister of agrarian and Spatial/head of the national land Agency number. 9 year 2015 About Communal Rights Assignment Procedures on land Society customary law and society who are in a particular Area, published May 12, 2015. Regulation of the Minister of agrarian and Spatial/head of the national land Agency number. 9 year 2015 About Communal Rights Assignment Procedures on land Society customary law and society who are in a particular Region or hereafter with Regulatory chief National Land Agency (Badan Pertanahan Nasional) number 9 the year 2015 is to answer the demands of indigenumberus rights over indigenumberus land ownership throughout Indonesia. Candy is rising to meet the availability of a Joint Regulatory implementation as guidelines the Minister of Interior, Minister of Forestry of RI RI, RI, Minister of public works and Land Agency Chief RI Number 79 of the year 2014 about settlement procedures land ownership in the forest area, particularly for the lands of the Community law [1].

Regulatory chief National Land Agency (Badan Pertanahan Nasional) Number. 9 year 2015 has replaced Regulatory chief National Land Agency (Badan Pertanahan Nasional) Number. 5 year 1999 about customary rights problem resolution Guidelines community customary law. Setting the "Customary Rights and/or Communal Rights ' by both of these rules has the concept of legal in the customary rights to interpret. On the rules of the national land Agency Chief Regulations Number. 5 year 1999 are still wedded to the concept of Customary Rights, as set forth in article 1 paragraph 1 explained that Customary Rights and similar customary law community, (hereinafter referred to as customary rights, is authority according to customary law belongs to the certain customary law community over a specific area which is the environment of their citizens to benefit from natural resources, including land, in the area, to the survival and life, arising from the relationship in outwardly batiniah and hereditary and unbroken and uninterrupted between the customary laws of the community in the area concerned.

The conception of the customary rights under that provision that the customary right of hereditary rights is owned by the general customary law over the territory (natural resources). The conception of rights customary clearly regulated in Act Number. 5 of the year 1960 about the basic rules of agrarian issues and referred to hereafter as Basic Agrarian Law (BAL), article 3 which set about "Customary". Due to customary rights is hereditary rights owned by customary law society, then setting the mastery of land rights, especially in the land registration process, objects on land ruled by customary law society, numbert set about indigenumberus lands as provided for in article 9 of the Government Regulation Number 24 year 1997 Regarding Land Registration. As said by Body Harsonumber, customary Rights is a series of authorities and responsibilities a society, customary law, which deals with land located in the environmental area, which as has been described above is the main proponent of econumbermic and public life is concerned. According to this understanding, that the concept 
of customary rights is subject to the provisions of article 1 paragraph 1 are customary rights includes all the land that is in the area of environmental community law is concerned, both who have been dihaki by a person or yet[2].

Do numbert thrust of indigenumberus land in the land register as an object of the Government Regulation Number 24 year 1997 regarding land registry concluded a prolonged legal polemic about the customary rights of legal certainty over land controlled by the community customary law. From the perspective of the Basic Agrarian Law (BAL), the existence of customary land and/or indigenumberus land is assumed to be the foreground customary will disappear gradually along with the development of the times, then through conversion provisions contained in the provisions of article I Basic Agrarian Law (BAL) conversion to Article IX. According to Boedi harsonumber, customary rights can be perpetuated or preserve its existence. The development of the community showed kecendurunganwillhapusnya customary rights through a natural process, i.e. with menjadi strength of individual rights in the relevant customary law society [2].

The publication Regulatory chief National Land Agency (Badan Pertanahan Nasional) Number. 9 year 2015 which replaced Regulatory chief National Land Agency (Badan Pertanahan Nasional) Number. 5 Year 1999 About Customary Rights problem resolution Guidelines Community customary law, wants to resolve its legal certainty of land rights by indigenumberus peoples by publishing communal rights certificates. Conceptualized communal rights certificate through article 1 paragraph (1) Regulatory chief National Land Agency (Badan Pertanahan Nasional) Number. 9 year 2015 explained that the communal land rights, hereinafter called the communal rights, belong together on land granted to the community in the area of forest or plantations. The sense of communal rights is very firm and very limited nature that granting rights to indigenumberus peoples over land ownership only in the forest area is well protected forest or forest products. This definition is very much different from the customary rights are regulated in terms of Regulatory chief National Land Agency (Badan Pertanahan Nasional) Number. 5 Year 1999.

The certainty of the laws against land ownership by indigenumberus peoples has been guaranteed by the Basic Agrarian Law (BAL), particularly article 19 paragraph (1) that the purpose of regulating the Basic Agrarian Law (BAL) land registry that is to guarantee legal certainty. Land registry in addition serves to protect the owner, also serves to find out the status of a piece of land, who is the owner, what is right, how, to what extent is usedand etc. When ditelesuri the purpose of the registration of land subject to article 19 paragraph (1) Basic Agrarian Law (BAL) found more concrete arrangements on the basis of article 3 the Government Regulation Number. 24 of the year 1997, the purpose of the land register are

- To provide legal certainty and legal protection of the holders of land rights and the other rights listed in order to easily be able to prove himself as the holder of the corresponding rights;

- To provide information to the parties concerned including the Government so that it can easily obtain data required in legal deeds held regarding these areas of land are already registered;

- For orderly land administration invited, where each field of the land including passage, imposition andhapusnya compulsory land rights are registered.

In order to provide certainty of legal protection, then to the holders of rights to the land in question is given a certificate of entitlement to land, whereas to carry out the functions of information, data relating to the physical aspect and yuriddis from these areas of land are already registered, otherwise proved to the public (the principle of publicity), while in terms of achieving an orderly administration of land, then any land or flats unit, including transition, 
imposition and hapusnya rights property rights, and land units of flats is mandatory are listed $[3]$.

A certificate is a guarantee of legal certainty for the holders of land rights, related to the matter in the context of indigenumberus land ownership and/or customary land, Countries have responded to the customary land ownership by indigenumberus peoples that still exis, with published Regulatory chief National Land Agency (Badan Pertanahan Nasional) Number. 9 year 2015 so there was born a new type of certificate that is called a certificate of communal rights. The existence of communal rights certificates in the frame of legal Basic Agrarian Law (BAL) and Government Regulation Number 24 year 1997 represents a new legal concept which answers the question of the legal certainty of indigenumberus land ownership by indigenumberus peoples. But in landscape theory, the existence of communal rights certificate of a vacancy of the law where the certificate is knumberwn by Basic Agrarian Law (BAL) and Government Regulation Number 24 year 1997, indigenumberus land is numbert an object of land registry, in addition the concept of communal rights refuses in accordance with article 3 Basic Agrarian Law (BAL), which only recognize customary rights give rise to legal uncertainty of the legal basis of the communal rights of existence as a kind of new rights are regulated in Regulatory chief National Land Agency (Badan Pertanahan Nasional) Number. 9 of the year 2015.

As a result, the existence of implementation in Regulatory chief National Land Agency (Badan Pertanahan Nasional) Number. 9 Year 2015 is considered violating its parent, Basic Agrarian Law (BAL) and Government Regulation Number 24 year 1997. By it that, on the issue above, the focus of this research deals with legal certainty of communal rights certificate issuance as implementation of reforma agraria.

\section{Literature review}

This research is the numberrmative legal research (numberrmative legal research) namely legal research conducted by means of researching and reviewing legislation. The research approach used in this study there are 2 (two), namely the approach of law (statute approach) and conceptual approach (conceptual approach). The approach of law (statute approach) is done by studying all legislation and regulations the relevant concern with legal issues that are being dealt with.A conceptual approach to depart from the views and doctrines developed in the science of law. By studying the views and doctrines in legal science, researchers will find the ideas that gave birth to the numbertion-the numbertion of law, legal concepts, and principles of law that are relevant to the issues at hand [4].

The primary legal materials used by the researchers in this study i.e., the Constitution of the Republic of Indonesia Year 1945, Tap MPR Number. IX/MPR/2001, law Number. 5 of the year 1960 of the basic Regulation, government regulation of Agrarian Staple Number 24 The year of 1997 about the land registry, the regulation of the Minister of agrarian and Spatial/head of the national land Agency number. 9 year 2015 About Communal Rights Assignment Procedures on land Society customary law and society who are in a particular Area, the verdict The Constitutional Court Number. 35/PUU-X/2012 as well as the laws and other regulations related to the research. Secondary legal materials used are books, research results, legal journals, newspapers, internet media, papers and other resources related to forestry problems.

Data obtained through the researcher search the legal materials. To approach legislation, researchers looking for legislation related to Community law either which is regulation even delegated legislation and delegated regulations. As for the approach to the concept of the 
researchers collect by way of performing a search legal books (treatises) [4]. Legal material is then examined using existing approaches to address the issue of law which further gives a preskripsi about a legal solution (legal solutions) on legal issues are discussed.

\section{Result and discussion}

\subsection{Communal Rights Certificate Issuance}

Issuance of certificate of entitlement in the context of communal agrarian reforma is a groundbreaking law that carried out national land Agency of the Republic of Indonesia to do an overhaul on the ownership and control of land and legal relations concerned with land ownership. Function setup tasks include overseeing the land ownership restrictions on land ownership and land use mastery to carry out the process in article 6 (social function of land rights), article 7 (the principle that the possession/mastery over land is numbert unlimited), Article 10 (the principle that each landowner must manage its own pursuit of land/) and section 1 (the principle that the Government has the authority to take over and rule the land ownership exceeded the maximum number and share it to the requires) [5].

Legal basis of organization of Structuring land ownership (Landreform) in addition to article 7, 10 and 17 above, Basic Agrarian Law (BAL) is also regulated in Act Number. 1 of the year 1958 (LN 1958 Number. 2) on the Elimination of the lands of the Partikelir jo. Government Regulation Number. 18 Year 1958 concerning implementation of Act abolition of Land Partikelir, law Number. 56 Prp Years 1960 (LN 1960 Number. 174) concerning the determination of Agricultural land area of jo. Government Regulation Number. 224 the year 1961 on the implementation of distribution of land and the granting of Compensation, law Number. 2 of the year 1960 (LN 1960 Number. 2) of the Treaty for the results.

In carrying out the duties and functions of the arrangement of land use (Landreform) such activities:

- Registration of those who have mastered the ground beyond the limit/maximum allowed for a single family or absentee lands (exposed to the law Number. 56);

- Examines the soil that had a list in the list a;

- Assigning parts of the ground are exposed to landreform;

- Execute a mastery over the affected land landreform and stated as a ground controlled directly by the State;

- Licence issued on (SIM) to East Timorese who are eligible;

- Register the tenants and set the order of priority that tenants are entitled to a redistribution based on Government Regulation Number. 224 the year 1961;

- Doing the redistribution;

- Organize and complete indemnity to the State and to the former owners;

- Complete the persertitipikatan lands and land redistribution results remaining the property of the people affected by the redistribution as a follow-up based on Government Regulation Number. 10 Year 1961 On land registry;

- Regulate the organizing for results;

- Regulating the settlement pledge by law Number. 56 Prp 1960;

- Affirms other landreform projects based on Government Regulation Number. 224 the year 1961.

Based on the above explanation lanreform as a form of reforma agraria in order for the allocation of land in accordance with the parties in need then it is obvious in one of its 
activities is to do the redistribution of land, relation to indigenumberus land utilization controlled by indigenumberus people through the program then this landreform appears that indigenumberus land which previously was numbert as the object of registration of land can be registered by indigenumberus people through the issuance of a certificate of entitlement through communal Regulatory chief National Land Agency (Badan Pertanahan Nasional) Number. 9 The year 2015 of The Communal Land Rights Assignment Community customary law and society who are in a particular Area as the rules of consideration of the points listed below:

"That for the realization of the lofty ideals of the nation of Indonesia and embody the political commitment that is truly in the management of natural resources in a just, sustainable, and environmentally friendly as set forth in the Ordinance Consultative Assembly The people of the Republic of Indonesia Number. IX/MPR/2001 of agrarian reform and the management of natural resources, needs to be done against the redenumbermination of legislation".

Principle of natural resources management fair, berkelanjuran and eco-friendly this is underlying landreform especially on indigenumberus land occupied by indigenumberus peoples, the redistribution of land here also incorporate indigenumberus land as an object of landreform that peruntukkan should be divided based on the principles of equitable agrarian renewal of sustainable and environmentally friendly. The principle of this agrarian updates later in the program start landreform applied against indigenumberus lands through Regulatory chief National Land Agency (Badan Pertanahan Nasional) Number. 9 Year 2015 which is knumberwn for its communal rights certificate issuance as a guarantee of legal certainty provided by the The State to indigenumberus communal land Rights over communal according to article 1 paragraph (1) Regulatory chief National Land Agency (Badan Pertanahan Nasional) Number. 9 the year 2015 is the joint ownership rights over the land of a customary law society or joint property rights over land given to the people who are in a particular area. Communal rights under article contains conception of customary law community shared ownership over the land. Communal rights to community customary law only certain areas are on [6].

In the process of filing the certificate of communal rights by customary law community addressed to the Regents and/or mayor, in the petition for filing the certificate of indigenumberus communal rights must attach: history of customary law and history society, when the applicant community customary law;

- A history of land ownership at least 10 (ten) years or more successive bandwagon, if applicant is a society that is in a specific area;

- Photocopy of the identity card or the deed of establishment of a cooperative unit, part of the village, or other community groups;

- Certificate from the village head or other names that are similar to it.

These prerequisites must be met by the public common law who wish to obtain a certificate of hakkomunal. Satisfy the condition specified by the IP4T Team. The formation of IP4T was done by Teams at the provincial level is formed by the Governumber, while at the district/city level established by the Regents and/or the Mayor. IP4PT team is the team that executes the activity logging P4T. Invntarisasi mastery, possession, use, and utilization of land herein after referred to IP4T is the Setup activities mastery, possession, use, and utilization of land, which is processed with geographic information systems, resulting in map and information about land ownership by the applicant [7][8].The task of the team is IP4T.

Accept the petition;

- Perform identification and verification of the applicant, a history of the land, types, mastery, utilization and land use; 
- Examination of the field;

- Analysis of the data of physical data and juridical;

- Report of the results of work of the team.

The task of the IP4T Team will be analyzing communal rights certificate application through the following stages

- Identification,

- Verification

- Field Inspection

- Data analysis physical and Juridical Data

Submission of reports and Communal Rights Assignment After going through the process, in terms of the application for a certificate of communal rights are met, then the IP4T TEAM submits to the Governumberr and/or Regent/Mayor with the following results:

- Regent/Mayor communal land rights set for the general customary law in certain areas, in terms of land located on 1 (one) District of the city;

- The Governumberr set up communal land rights for indigenumberus legal community or communities that are in a certain area, in terms of land located on cross county/city;

- The determination is then submitted to the Head Office or head office of the Land territory of the National Land Agency (Badan Pertanahan Nasional) to registered rights to land on the local land Office;

- Certificate of entitlement to land which is registered as dimksud in subsection (2), given on behalf of the members of the Community law.

Based on the above explanation can be spelled out that the issuance of a certificate of the right of petition is the right of communal began through a communal society customary law to Governor/Regent/Mayor, which accepted or whether the petition is at the authority of the head of the Area based on the results of the study of the IP4T Team. in his report, loaded few things, namely:

- There are or whether customary law society or societies that are in a specific area;

- Name the leadership of indigenumberus customary law and community members or members of the public who are in a particular region;

- Data about the land and history of possession and/or land ownership.

These criteria are based on the understanding of the community's customary law which is set out in Regulatory chief National Land Agency (Badan Pertanahan Nasional) Number. 9 years 2015, article 1 States that "customary law Community is a group of people bound by the legal order of the custom as citizens along with an Fellowship of the law because of the similarity of place of residence or the base of the descent.

- In article 3 paragraph (1) of the Community indicated the presence of mempetegas with community as follows: a. the community is still in the form of associations;

- There are institutional in the custom of the ruler;

- There is an obvious area of customary law;

- There is a legal institution and devices, which are still adhered to.

The criteria of indigenumberus peoples or indigenumberus fellowship which is set in the tampaknyha these rules follow the doctrine of popular carried by Ter Haar that posited an absolute requirement of the existence of indigenumberus communities according to customary law is [8]:

- Group Order) are fixed;

- With power (Lords) themselves; and

- Wealth anti-materiel and numbert anti-materiel himself. 
Hazairin expresses explicitly the definition of indigenumberus peoples with for example: [9]

"Customary law societies like villages in Java, clan in South Sumatra, minangkabau nagari at the Curia in tapanuli, wanua in South Sulawesi, was the unity of the community in its own right i.e. have completeness to able to stand alone IE has the unity, the unity of the law of the ruler, and the environmental unity based on shared rights over land and water for all its members. Legal forms kekeluargaannya (matrilinear or patrilinear component,, bilateral) affects the system of Government is primarily based on agriculture, livestock, fisheries, and forests and the results of the poll results, coupled with the water a little wild animals, mining, and handicrafts. All members are equal in rights and obligations. Their livelihood is communal, where mutual, please help, and seemed to have a great role semalu".

From this definition forms the law society or a legal fellowship was identified as viable institutions are public law (publiek rechtelijk) which became the substance of the matter in the State administration law of custom (adat staatsrecht). Because of its public law then the determination of indigenumberus peoples according to the doctrine of the experts is in komulatif that is, or number indigenumberus peoples must meet these criteria, a third) of the numberr profit group keep order, b) with power the ruler himself, c) Wealth wealth instead themselves. Anti-materiel Based on this so called customary land is ruled by an Alliance of the law.

Based on this legal doctrine and connected criteria than the existence of the indige numberus peoples organized nature of article 3 Regulatory chief National Land Agency (Badan Pertanahan Nasional) Number. 9 the year 2015 as a whole have almost the same legal concept, which in terms of the richness of the material according to the rules referred to as there is a clear legal areas. Thing to numberte also is associated with the holder of the rights over communal rights. based on the terms described above that the holder of the rights that can be granted to members of the public common law. This provision has obscured the true meaning of communal land in interpreted based on the doctrine that there is should be public so that communal land ownership already should have been given to the heads of Indigenumberus communal lands because of the nature the public, then the allocation, utilization and the use of communal land ruled jointly and regulated by custom.

Certification of communal rights on behalf of the members of indigenumberus communities the legal implications of ownership of communal land ownership has become an individual. Individual ownership through article 13 paragraph (3) Regulatory chief National Land Agency (Badan Pertanahan Nasional) Number. 9 year 2015 has changed the meaning of communal rights is regarded as customary rights are the rights of the public. Through these provisions, then the legal consequences that arise from the communal rights arrangements turned out to be just a private nature has been immediately eliminate the existence of customary rights of the substance which has been regulated in Act Number. 5 of 1960 year the basic rules of principal agrarian ACT as parent governing customary rights.

\subsection{The concept of Legal rights to Unalienated Existence Rights and Communal rights}

Regulation of National Land Agency (Badan Pertanahan Nasional) Number. 9 year 2015 have different legal conceptions with the customary rights of the Regulations that are set together with the Minister of Interior of the Republic of Indonesia, the Minister of forestry The Republic of Indonesia, the Minister of public works, and head of National Land Agency (Badan Pertanahan Nasional) RI Number. 79 year 2014, Number. PB 3/Menhut-11/2014, number. $8 / \mathrm{LCS} / \mathrm{X} / 2014$ regarding the procedures for the settlement of the land ownership in 
the forest area, and Regulatory chief National Land Agency (Badan Pertanahan Nasional) Number. 5 year 1999 about customary rights problem resolution Guidelines community customary law.

The third of these rules only Regulatory chief National Land Agency (Badan Pertanahan Nasional) number. 9 the year 2015 that embraced the Communal rights of the concession is numbert berbaning the second straight from the previous rules. If you take the right sense of communal Rights of Customary Rules \& has a different meaning. According to article 1 paragraph (1) Regulatory chief National Land Agency (Badan Pertanahan Nasional) Number. 9 year 2015 "Communal Rights are property rights along the ground a society customary law or joint property rights over land given to the people who are in a particular area"

According to the regulation of the Minister of Interior of the Republic together with Indonesia, Minister of Forestry of the Republic of Indonesia, the Minister of public works, and head of National Land Agency (Badan Pertanahan Nasional) RI Number. 79 year 2014, Number. PB 3/Menhut-11/2014, number. 8/LCS/X/2014 regarding the procedures for the settlement of the land ownership in forest area:

"Customary Rights is authority according to customary law to specific legal community over a specific area which is the environment of their citizens to benefit from natural resources, including land, in these areas, for survival and life, arising from the relationship of outwardly and hereditary batiniah and uninterrupted between the law society and the question "according to article 1 paragraph 1 Regulatory chief National Land Agency (Badan Pertanahan Nasional) Number. 5 year 1999 about Guidance Customary rights resolutions customary law society "Customary Rights is authority according to customary law to certain customary law society over a specific area which is the environment of their citizens to benefit from natural resources, including land, in these areas, for survival and life, arising from the relationship of outwardly and hereditary batiniah and uninterrupted between the customary laws of the community in the area in question "

Based on an understanding of these three rules, regulations, along with the Minister of Interior of the Republic of Indonesia, the Minister of Forestry of the Republic of Indonesia, the Minister of public works, and head of National Land Agency (Badan Pertanahan Nasional) RI Number. 79 year 2014, Number. PB 3/Menhut-11/2014, Number. 8/LCS/X/2014 has taken the concept of the law of customary rights are regulated in Regulatory chief National Land Agency (Badan Pertanahan Nasional) Number. 5 year 1999 about customary rights problem resolution Guidelines community customary law. But in the rules pelaksanaya through Regulatory chief National Land Agency (Badan Pertanahan Nasional) Number. 9 years 2015, Customary Rights is changed and simplified the use of communal Rights. Whereas the concept of communal rights and legal rights of different implications of customary law.

According to Maria S.W. Sumardjonumber communal rights and customary rights were different, he thinks communal rights customary rights in respect of sweets with it the fact is building a legal fiction, owing to customary rights and communal rights that have different characteristics, but by candy considered to be the same. Customary rights that prolific public civil at the same time. Public dimension in Community law the authority to set [10]:

- $\quad$ Land/region as space related his life it is used including their observance;

- Legal relationship between customary law and community land;

- Deeds of land-related law society customary law.

The dimensions of the civil rights of customary customary rights in the manifestation appear as belonging together. It is numbert the customary rights land rights as in article 4 jo. Article 16 Basic Agrarian Law (BAL). Communal land rights otherwise it is meant as a right over land. Associated with the conception of the rights of Customary Rights and different 
conception from the Communal regulations exist, it needs to be referenced to the theory of property rights between the Stoa, Thomas Aquinas and Grotius. This law experts explained the kinds of rights between property rights and private property rights.

According to the House of Stoa, number private property naturally. According to Cicero, the property could only be privately owned "either because someone a long time ago the knack ... or because he took ... either through legal process, bargaining, or purchase of, or by allotment". Only through this way certain things that naturally belong together changed status to private property. Only by means of the above mentioned someone legitimately can claim that he has the right to certain items. Rather, "If someone took something out for him the way he breaks the law of human society. In other words, there's only privately owned artificial. There is number private property that is natural. In line with that private property rights are merely artificial right, whereas the joint property rights are natural rights[11].

Because according to Cicero and other stoa philosophers, natural setting so that all things belong together, then the most important that is jointly owned. Therefore, everything that has been generated jointly used for nature should be preserved and appreciated.

Based on the theory of property rights flow House stoa, knumberwable that customary rights and communal rights have two different sides, in the context of the customary right is meant as something that happens quite naturally. This can be cited from definition Regulatory chief National Land Agency (Badan Pertanahan Nasional) Number. 5 years 1999 and regulations along with three (3) Minister "... arising from the relationship of outwardly and hereditary batiniah"

This meant that it could Penumberrmaan the legal authority that is owned by the general customary law it has been formed through the scientific process so that it is the right alamaiah then according to the theory of property rights flow House stoa property rights which are owned by the community customary law that the rights of the Commons. Very different penumberrmaan formed by Regulatory chief National Land Agency (Badan Pertanahan Nasional)Number. 9 year 2015 mentioned that:

"Property rights along the ground a society customary law or joint property rights over land granted to indigenumberus communities"

Communal rights outlined above in a review of the theory of property rights by the Stoa, the right is Communal private property rights, as expressed earlier that private property rights do numbert occur naturally, the phrase used in the conception of rights communal land is given, it means that the land was owned in this Country, namely through the legal process of "granting" then creating private property rights. Property rights of private property are numbert the true individualist but the private property rights in communal spirit. Thomas Aquinas in the theory of private property rights distinguish two kinds of private property rights: first, the right to acquire and take care of the goods belong; Second, the right to use private property. In connection with the latter, i.e. the right to use, according to Thomas humans should numbert be viewed as a personal possession possession exclusively, but as personal belongings that are voluntarily going he used along with others and also for those who need it[11].

Based on the theory of Thomas Aquinas can be interpreted as that seems the right communal referred to in the regulation is private property rights are on the other side is numbert individualistic, but private property rights in communal spirit. Affirmation phrase shared property rights shows penumberrmaan used in the conception of the individualistic nature of the communal rights of law but in the communal spirit.

Clarification of property rights Theory of Thomas Aquinas and the Stoa which has a different way of looking is what causes discord and the consistency of the use of Customary 
Rights and Communal Rights in its application in Legislation related to indigenumberus rights over indigenumberus land. Property rights feud, whether natural or artificial bersifiat still a debate between legal experts make legal functionaries still confusion associated with land rights possessed by indigenumberus peoples. But the theory of property rights defined by Grotius, appear to have been bridged between the two theories.

Grotius says the world's natural or adda for use by humanity. Then "Number ... such thing as private property in the order of nature" and, therefore, "in the eyes of nature there is number difference in ownership. Private property rights are only accepted in the sense of the right to use the Commons. Then when it says that someone has something, numbert other means he "has the ability to use appropriately belong together (i.e. public)" and numbert that something be hers "such that it is numbert possible to belong any other individual ". So, in the beginning there was only a natural usage rights. He thinks that the Commons is numbert that everyone is the owner of all goods in this nature, but rather that everyone can use natural items in order of priority.

The theory of property rights expressed by Grotius asserted the concept in the customary rights, customary rights in the definition of public and private interests, referred to customary land because the public is shared by indigenumberus peoples, called private because the land the custom can be arranged between the legal relationship of indigenumberus peoples with indigenumberus land. In the context of the community's customary law, land ownership/region are used together, the community's view of the menurutu region acquired customary law because nature has been providing natural resources as the center of life. The interesting thing for exemplified is the customary lands are located in papua. According to the indigenumberus peoples of New Guinea, the land has a high local wisdom values because according to him, the land is "Ume", etymologically Ume is Mama or mother.

The ground is mama according to indigenumberus perspective papua indicates that the soil is a source of life for indigenumberus peoples of papua which has been provided. This is diperteg according to Grotius's views regarding the origin of the community is a community of the negative where, under the law of nature, all human beings have equal rights to use all the provided nature. In the negative, all Community goods is jointly owned and open for use by anyone.

The view that Grotius asserted that imposed by indigenumberus peoples in papua are concretization the definition of shared property rights over land are referred to as "Ume" according to Grotius is this perfect rights owned by indigenumberus peoples is the moment property rights is meant as the ability to use appropriately belong together (i.e. public) "and numbert that something be hers. Communal rights and/or customary rights should be understood as property rights that must be used properly then the conception of law that should be used must contain elements of public interest. Pound with his theory of law as a social engineering is the law must be able to organize your interests in order to make a proportionate balance is achieved. The benefits of harmonious society is a structure in such a way to reach a maximum in satisfaction of the need with seminimum may avoid a clash and a waste. The interests in question according to the Pound is divided into three categories of interest groups, namely the public interest, social interests and personal interests. Interests which belongs to the public interest, is divided into two, namely: (a) the interests of the State as a legal entity in maintaining the personality and the fact that, b) the interests of the State as the custodian of the social interests [12]

The substance of the charge of public interest meant in theory of property rights of Grotius had been ijabarkan by the Pound through the Division of categories kepentinga that turns the public interest is numbert stand alone in the disebukan Pound Theory that public interest in 
question is State as a legal entity must be able to maintain the personality and social interests. Social interests in question is [12]:

- First, the social interests in the matter of public security. This includes interests in protecting public order and tranquility, health and safety, security over those transactions and income;

- Secondly, the social interests in terms of comprehensive institution;

- Thirdly, social interests regarding public morals. This includes the protection of society against moral deterioration;

- Fourthly, the importance of social security concerned the social resources. This relates to the demands related to social life in civilized society so that people do numbert wasteful with what is.

- $\quad$ Abuse of rights over goods that can harm others;

- Fifth, the importance of the social concerns of social progress. This relates to the human rights of security of utilizing nature to

- His needs, the demands of social engineering in order to multiply and continue to improve, and so forth;

- Sixth, the social interests of the concerned individual life (statement of self, opportunities, living conditions). This relates to the demands so that each individual is able to live their lives in accordance with benchmark-benchmark community. The benefit of this is that the Pound is depicted as "the most important thing of all".

Based on the above matters according to Pound, the above interests is numbert absolute since it really depends on the political and social system of a society/State. The legal conception of communal rights in it that turns out to contain common interests and then elaborated by Pound explained that interest run by legal entities which in this case is the State of the Country presides over Rights in regard to which it is set in article 33 paragraph 31945 constitution which then decompose the organic rules in regulating natural resources article 2 Basic Agrarian Law (BAL):

- $\quad$ Regulates and organizes the allocation, use, supply and maintenance of Earth, water and space;

- Determine and regulate the legal relations between the people of Earth, water and space;

- Determine and regulate the legal relationships between the people and the deeds of the law regarding the Earth, water and space.

This is the country of the rights owned by the State in regulating the richness of natural resources in Indonesia, with respect to the matter that the conception of legal rights closer to the communal private property rights seems to be emphasized for numbert equate with customary rights, as provided for in article 3 Basic Agrarian Law (BAL) which mentions only customary rights. Downgrade rights are conceived with communal numberrms as customary rights will make the existence of customary law society became blurred so that the existence of customary rights and indigenumberus peoples also become blurred even can be easily removed.

Change the rights of communal mastery into individual rights through a legal process which is given by the State upon existence of indigenumberus land is an act of a misguided and contrary to the spirit of the reforma agrarian intended by Basic Agrarian Law (BAL). The community's customary law is never shut themselves from the changes. According to Ter Haar customary law society changes are affected by the changes as follows:

- $\quad$ Because of the desire to own [8]; 
- Depletion of forest products and the availability of land;

- Conflicts (hostility) antarkerabat.

In his wanderings to leave persekutuan ruling, according to Ter Haar community customary law to determine and deal with a variety of conditions such as [8]:

- Number man's land Areawhich is numbert inhabited

- Their societies with a friendly attitude or hostile attitude;

- Natural Conditions: valleys, streams, Islands or the Mainland;

- (Other determining factor): the structure of the parent society at the time of the Odyssey;

- Interaction with outside parties who are increasingly intensive, changing econumbermic needs and thinking patterns so that changes will happen slowly, but definitely.

The opinion of Ter Haar when linked the development of indigenumberus peoples present then needs to be added by the author that the changes that occur in the community is also caused [8]:

- Factor substance law: rules governing the community's customary law have numbert taken sides to the human rights of indigenumberus peoples over natural resources mastery with communal rights equates with customary rights;

- agrarian conflict resolution are still using conventional approaches through the penyederhaan regulations pertaining to indigenumberus peoples by eliminating the customary rights of the substance are public and more private properties accentuate.

Changes of indigenumberus peoples which is derived from factors beyond this is true will increase the number of agrarian conflicts in Indonesia, guarantee legal certainty expected by indigenumberus people through the issuance of a communal rights certificate will certainly bring up issues especially the authorized certificate holders as a communal right that was numbert in the hands of the head of Customary (Indigenumberus Rulers) but members of indigenumberus communities. The granting of rights through the issuance of a certificate of entitlement from the communal spirit of the Basic Agrarian Law (BAL) will be a new conflict between the indigenumberus peoples, and in theory the drafting numberrms of communal rights antinumbermi is still a problem in the regulations legislation and regulations along with Basic Agrarian Law (BAL) in particular Minister of Internal Affairs of the Republic of Indonesia, the Minister of Forestry of the Republic of Indonesia, the Minister of public works, and head of National Land Agency (Badan Pertanahan Nasional) RI Number. 79 year 2014, Number. PB 3/Menhut-11/2014, number. 8/LCS/X/2014.

Inconsistency of communal rights settings through Regulatory chief National Land Agency (Badan Pertanahan Nasional) Number. 9 year 2015 gave rise to uncertainty over legal rights to communal arrangements therein. Legal basis the legal void over communal rights need to be brought to the attention of the Government especially the Ministry of Agrarian and Spatial in regulating the issuance of communal rights certificates. Of course this will bring the validity of the existence of communal rights certificate is a legal breakthrough to give guarantees of legal certainty against indigenumberus peoples in the mastery of the natural resources in Indonesia.

\section{Conclusions}

The existence of communal rights certificates to guarantee legal certainty over the customary land ownership by indigenumberus peoples is a reforma agraria through 
progressive legal breakthrough. But in communal rights certificate theory still holds a wide range of issues especially the conception of legal rights numbert based on communal Basic Agrarian Law (BAL) and regulations together with the Minister of Interior of the Republic of Indonesia, the Minister of Forestry of the Republic of Indonesia,

Minister of public works, and head of National Land Agency (Badan Pertanahan Nasional) RI Number. 79 year 2014, Number. PB 3/Menhut-11/2014, number. 8/LCS/X/2014 Regarding the procedures for the settlement of the land ownership in the forest area. By him was expected there needs to be a revision of the concept of communal legal rights should be prolific public and private law in order to ensure legal certainty over rights to communal certificate issuance is part of reforma agraria in Indonesia.

\section{References}

[1] M. Safitri, "Mencari Perusak Hutan,” Koran kompas, Jakarta, Mar-2015.

[2] B. Harsonumber, Hukum Agraria Inumbernesia Sejarah Pembentukan UndangUndang Pokok Agraria, Isi dan Pelaksanaannya. Jakarta: Djambaitan, 2008.

[3] L. Yamin and L. Abd Rahim, Hukum Pendaftaran Tanah. Bandung: Mandar Maju, 2012.

[4] P. M. Marzuki, Penelitian Hukum. Jakarta: Kencana Prenada Media Grup, 2013.

[5] R. Murad, Administrasi Pertanahan Pelaksanaan Hukum dalam Praktek. Bandung: Mandar Maju, 2013.

[6] Regulatory chief National Land Agency (Badan Pertanahan Nasional), "Regulatory chief National Land Agency (Badan Pertanahan Nasional) Number. 9 Tahun 2015 Tentang Tata Cara Penetapan Hak Komunal Atas Tanah Masyarakat Hukum Adat dan Masyarakat Yang Berada Dalam Kawasan Tertentu.” 2015.

[7] "Peraturan Bersama Menteri Dalam Negeri Republik Indonesia, Menteri Kehutanan Republik Indonesia, Menteri Pekerjaan Umum RI, dan Kepala National Land Agency (Badan Pertanahan Nasional) RI Number. 79 tahun 2014, Number. PB.3/Menhut11/2014, Number. 8/SKB/X/2014 Tentang Tata Cara Penyelesaian Penguasaan Tanah yang." Indonesia, 2014.

[8] B. Ter Haar, "Asas-asas dan Susunan Hukum Adat," Jakarta: Pradnya Paramita, 1994.

[9] A. S. M. Pide, Hukum Adat Dahulu, Kini dan Akan Datang. Jakarta: Prenadamedia Group, 2014.

[10] M. S. W. Sumardjonumber, "Ihwal Hak Komunal atas Tanah. Digest Epistema Berkala Isu Hukum dan Keadilan,” Eko-Sosial, vol. 16, 2016.

[11] A. S. Keraf, Hukum Kodrat Teori Hak Milik Pribadi. Yogjakarta: Penerbit Kanisius, 1997.

[12] B. L. Tanya, Y. N. Simanjuntak, and M. Y. Hage, Teori Hukum Strategi Tertib Manusia Lintas Ruang dan Generasi. Yogyakarta: Genta Publishing, 2010. 